\section{Atomic Absorption Spectroscopic Determination of Heavy Metal Concentrations in Kulufo River, Arbaminch, Gamo Gofa, Ethiopia}

Tsade HK* $^{*}$

School of Applied Natural Sciences, Department of Applied Chemistry, Adama Science and Technology University, Adama, Ethiopia

\begin{abstract}
Heavy metals are common pollutants in River mainly due to traffic emissions to it. The present project work was focused to study $\mathrm{Mn}, \mathrm{Cr}, \mathrm{Cd}$ and $\mathrm{Pb}$ concentrations in Kulufo River, Arba Minch, Gamo Gofa. In the present work, the water sample was collected from Kulufo River randomly and analyzed for the concentrations of $\mathrm{Mn}, \mathrm{Cr}, \mathrm{Cd}$ and $\mathrm{Pb}$. The concentrations of $\mathrm{Mn}, \mathrm{Cr}, \mathrm{Cd}$ and $\mathrm{Pb}$ were analyzed with the help of Flame Atomic Absorption Spectrometry (FAAS). The levels of $\mathrm{Mn}, \mathrm{Cr}, \mathrm{Cd}$ and $\mathrm{Pb}$ in the studied River water ranges from (0.420-520, 0.012-0.023, 0.106-0.201 and 0.050-0.108) $\mathrm{mg} \mathrm{L}^{-1}$ respectively. From these concentrations, all the concentration obtained for $\mathrm{Mn}, \mathrm{Cr}, \mathrm{Cd}$ and $\mathrm{Pb}$ were greater than the concentration reported by World Health Organization (WHO). This shows that the presence of $\mathrm{Mn}, \mathrm{Cr}, \mathrm{Cd}$ and $\mathrm{Pb}$ in the study area has a significant influence to health. Especially, $\mathrm{Pb}$, and $\mathrm{Cd}$ exhibited high significance toxicity effect even at lower concentration.
\end{abstract}

Keywords: River water; Manganese; Lead; Chromium; Cadmium and flame atomic absorption spectroscopy

\section{Introduction}

River water has been and is still being used for many purposes, which include drinking, irrigation, animal farming, recreation and serves as habitat to numerous organisms. The availability of good quality water is an indispensable feature for preventing diseases and improving quality of life [1]. Thus the River water contains some types of impurities whose nature and amount vary with source of water. Among environmental pollutants, heavy metals are of particular concern, due to their potential toxic effect and ability to bio-accumulate in aquatic ecosystems [2]. Increased urbanization and industrialization are to be blamed for an increased level of trace metals, especially heavy metals, in our waterways. Many dangerous chemical elements if released into the environment accumulate in the soil and sediments of water bodies. Therefore, to reduce the accumulations of heavy metals monitoring and assessment of the heavy metal concentration has become a very critical area of study in recent years.

The contamination of River water by heavy metals is a serious worldwide ecological problems in general and Ethiopian ecological problems in particular as some of them like $\mathrm{Hg}, \mathrm{Cd}$ and $\mathrm{Pb}$ are toxic even at low concentrations, are non-degradable and can bioaccumulate through food chain. The contamination of River water is directly related to the water pollution. Therefore, there is need to continuously assess the quality of River, ground and surface water sources. These assessments are carried out by using spectroscopic technique known as atomic absorption spectroscopy (AAS). Atomic absorption spectrometry is an analytical technique that measures the concentrations of elements qualitatively and quantitatively. If light of just the right 1 impinges on a free, ground state atom, the atom absorbs the light as it enters an excited state in a process known as atomic absorption.

The presence of heavy metals in aquatic ecosystem has far-reaching implications directly to the biota and indirectly to man. They also cause irregularity in blood composition, badly effect vital organs such as kidneys and liver. Heavy metals including both essential and nonessential elements have a particular significance in ecotoxicology, since they are highly

Persistent and all have the potential to be toxic to living organisms [3]. Heavy metals such as $\mathrm{Fe}, \mathrm{Mn}, \mathrm{Cr}, \mathrm{Ag}$ etc are phytotoxic at higher concentration and cause considerable amount of environmental degradation and ecological damage to water, air and soil [4]. Lead is particularly toxic to the brain, kidneys, reproductive system, and cardiovascular system because of chronic and acute exposure and the repeated exposure of $\mathrm{Pb}$ buildup in the body. Therefore, the determination of heavy metals $(\mathrm{Mn}, \mathrm{Pb}, \mathrm{Cr}$ and $\mathrm{Cd})$ concentration is paramount important in this study.

Studies done on heavy metal levels determination in rivers, lakes, fish and sediments [5-10] in different countries have been a major environmental focus especially during the last decade. Thus, Kulufo River is found in Ethiopia five hundred five kilometers away from Addis Ababa, Ethiopia's capital city and is a water source for many inhabitants in Ethiopia. The river whose source is from the Gamo high lands is in a region that has experienced high levels of agricultural development. Both agriculture and industrial processes drain their agro-industrial toxic waste containing high levels of phosphates, nitrates, and chromium, lead and dioxin compounds into the river. Thus, initiates the researcher to study about the determination of heavy metal concentrations from Kulufo River, Arba Minch, Gamo Gofa, by using atomic absorption spectrometry (AAS). Therefore, the objective of the study was to evaluate the levels of accumulations of some heavy metals such as $\mathrm{Mn}, \mathrm{Pb}, \mathrm{Cr}$ and $\mathrm{Cd}$ in Kulufo River, Arba Minch, Gamo Gofa, by using Flame Atomic Absorption Spectroscopy (FAAS).

\section{Materials and Methods}

\section{The study area}

Arba Minch is one of a town in Gamo Gofa Zone, SNNP regional state in Ethiopia found around five hander five kilometers away from Addis Ababa, Ethiopia's capital city. The local known name for this town is Ganta Garo (the place in which Ganta People live together) and the town got its present name from forty springs that found in this most tourist attractive town five kilometer far. Kulufo River is a water source for many inhabitants in Arba Minch area for farm lands, for domestic activities, etc. The river whose source is from the high lands of Gamo region is in a region that has experienced high levels of agricultural development.

*Corresponding author: Tsade HK, School of Applied Natural Sciences, Department of Applied Chemistry, Adama Science and Technology University, Adama, Ethiopia, E-mail: hizts4@gmail.com

Received March 24, 2016; Accepted March 27, 2016; Published March 31, 2016

Citation: Tsade HK (2016) Atomic Absorption Spectroscopic Determination of Heavy Metal Concentrations in Kulufo River, Arbaminch, Gamo Gofa, Ethiopia. J Environ Anal Chem 3: 177. doi:10.41722380-2391.1000177

Copyright: (C) 2016 Tsade HK. This is an open-access article distributed under the terms of the Creative Commons Attribution License, which permits unrestricted use, distribution, and reproduction in any medium, provided the original author and source are credited. 


\section{Apparatus}

The following apparatus were used in order to perform the project work. Different size beakers, measuring cylinders, micropipette, volumetric flasks, burettes, funnel, test tubes, thermometer, stopwatch, oven, electronic-mill, plastic bottels, erlenmeyer flask (different sizes), refrigerator, filter papers.

\section{Chemicals}

All chemicals of high purity analytical grade reagents were employed; $\mathrm{HNO}_{3}$ (69\% LR, Breckland Scientific Supplies, U.K) and $\mathrm{HCl}$ (35-38\%, Blulux, Laboratory reagent, U.K) were used for both extraction and acid digestion procedures. Titrisol standard $1000 \mathrm{mg}$ of $\mathrm{Pb}\left(\mathrm{NO}_{3}\right)_{2}$, and $\mathrm{KMnO}_{4}$, (Merck, Germany) dissolved in $1000 \mathrm{~mL}$ distilled water used for preparation of stock standards of $1000 \mathrm{mg}$ $\mathrm{L}^{-1}$ and intermediate standard solutions of $100 \mathrm{mg} \mathrm{L}^{-1}$ of $\mathrm{Mn}, \mathrm{Cr}, \mathrm{Cd}$ and $\mathrm{Pb}$ metals. Distilled water was used throughout the experiment to prepare all the solutions.

\section{Apparatus}

The following apparatus were used in order to perform the project work. Different size beakers, measuring cylinders, micropipette, volumetric flasks, burettes, funnel, test tubes, hydrometer, thermometer, stopwatch, ceramic mortar and pestle, $2 \mathrm{~mm}$ sieve, oven, electronic-mill, plastic bags, stirrer, erlenmeyer flask (different sizes), refrigerator, filter papers No. 42.

\section{Instrumentation}

Digital analytical balance used for all measurements of samples and chemicals. FAAS was used to determine the concentrations of $\mathrm{Mn}, \mathrm{Cr}$, $\mathrm{Cd}$ and $\mathrm{Pb}$. A potentiometric digital $\mathrm{pH}$ mete was used to determine the $\mathrm{pH}$ of water samples. Conductivity meter was used to measure the conductivity of water sample solutions.

\section{Sample collection}

Ten water samples were randomly collected from different points in Kulufo River sampling was carried out across the two major seasons in the study area from April-August 2015. Before to this, the plastic bottles were rinsed with $0.02 \mathrm{M} \mathrm{HNO}_{3}$ to maintain the constant $\mathrm{pH}$ and minimize loss of sample because of variation in $\mathrm{PH}$, evaporation, precipitation and other relevant physical and chemical properties. Samples were collected from Kulufo River located around Arba Minch Town and collected randomly using acidified plastic bottles and mixed. The bottles were filled and then sealed tightly to avoid head space that cause loss of samples because of oxidation.

\section{Physico-chemical analysis of water}

The physico-chemical analysis of water such as PH, TDS, Temperature and $\mathrm{EC}$ were done by using $\mathrm{PH}$ and electrical conductivity meter.

\section{Digestion of River water}

The digestion procedure for River water was carried out by transferring a measured volume $(50 \mathrm{~mL})$ of well mixed acid preserved water sample to a flask. Then $5 \mathrm{~mL}$ of conc. $\mathrm{HNO}_{3}$ and a few boiling chips were added into the flask. The mixture were boiled and evaporated on a hot plate to the lowest volume possible (10 to $20 \mathrm{~mL}$ ). Continue heating and adding conc. $\mathrm{HNO}_{3}$ as necessary until digestion is complete as shown by a light color clear solution. Do not let sample dry during digestion. After this the flask were wash down with water and filtered. Then the filtrate was transferred into $10 \mathrm{~mL}$ volumetric flask with two 5
$\mathrm{mL}$ portions of water, adding these rinsing to the volumetric flask and cooled and diluted to the mark and mixed thoroughly. A portion of this solution was taken for required metal determinations.

\section{Method detection limit}

A method detection limit (MDL) is the minimum concentration of a substance that can be measured. The determinative procedures involve digesting and diluting the blank solutions and then analyzing the concentration of each element of the samples. Then, the standard deviations of the triplicate readings of seven blanks were calculated. The standard deviations were multiplied by three to give MDL.

\section{Metal analysis of water}

In metal analysis procedure, atomic absorption spectroscopic standard solutions containing $1000 \mathrm{mg} \mathrm{L}^{-1}$ (Buck Scientific) were used for preparing intermediate standards and working standards. The intermediate standards were prepared by using dilution method. Also the working standard solutions were prepared freshly by appropriately diluting the intermediate standards with distilled water.

$\mathrm{Mn}^{7+}$ and $\mathrm{Pb}^{2+}$ were analyzed with the FAAS using calibration curves after the parameters (lamp alignment, wave length and slit width adjustment and burner alignment) was optimized for maximum signal intensity and sensitivity of the instrument. The wavelength and slit width were selected and adjusted at the beginning of the analysis and was constant up to the end of the analysis. This condition was performed in the same way throughout the study period.

\section{Results}

In this work, the conductivity of the River water sample collected from the selected site was determined at different temperatures and reported at $25^{\circ} \mathrm{C}$ with temperature corrections. In the selected site such as Kulufo River mean values of conductivity determined in this study (10.5-13.9 mS/m), which were below the WHO guidelines of $600 \mathrm{mS} / \mathrm{m}$ (Table 1). As expected, higher electrical conductivity values were determined in the wet season. Thus, the clarity of water is determined by its Electrical conductivity value, and having high conductivity water is an indicator of the presence of suspended solids, ions and microorganisms. This indicates that the River is suitable for aquatic life. In line with this, [11], indicated that the standard value of electrical conductivity of River water is $0.300 \mathrm{mMho} \mathrm{cm}^{-1}$. The average $\mathrm{pH}$ values determined in this study varied between 7.2 and 7.6 (Table 2) and complied with WHO guidelines for domestic water use. According to Ahmed and Rahman [12], River water with a $\mathrm{pH}$ ranges from 5.6 to 6 are moderately acidic, River water with a $\mathrm{pH}$ range from 6.1 to 6.5 are slightly acidic, River water with a $\mathrm{pH}$ ranges from 6.6 to 7.1 are neutral or nearly neutral, River water with a $\mathrm{pH}$ range from 7.2 to 7.8 are slightly alkaline and River water with a $\mathrm{pH}$ ranges from 7.8 from 8.4 are moderately basic and River water with a $\mathrm{pH}$ above 8.5 are strongly alkaline. Thus, the standard value for River water ranges from 6.5 to 8.5 [13]. Therefore, the value obtained from the study area was slightly alkaline.

\section{Method detection limit}

The method detection limits were slightly higher than the detection limit of FAAS. It was calculated as the concentration three times the standard deviation of the signals of the blank solutions (Table 2).

\section{Levels of heavy metals ( $\mathrm{Mn}$ and $\mathrm{Pb}$ ) in Mojo River water}

Manganese (Mn): Mn plays several roles in physiological processes in living organisms, including humans. It is a major component 
Citation: Tsade HK (2016) Atomic Absorption Spectroscopic Determination of Heavy Metal Concentrations in Kulufo River, Arbaminch, Gamo Gofa, Ethiopia. J Environ Anal Chem 3: 177. doi:10.41722380-2391.1000177

Page 3 of 3

\begin{tabular}{|c|c|c|c|c|c|}
\hline Metals & $\begin{array}{l}\text { Conc. of stock } \\
\text { solutions }\left(\mathrm{mg} \mathrm{L}^{-1}\right)\end{array}$ & $\begin{array}{l}\text { Conc. of intermediate } \\
\text { solutions }\left(\mathrm{mg} \mathrm{L}^{-1}\right)\end{array}$ & $\begin{array}{l}\text { Conc. of standard series } \\
\left(\mathrm{mg} \mathrm{L}^{-1}\right)\end{array}$ & Correlation coefficient & $\begin{array}{l}\text { Method detection limit } \\
\left(\mathrm{mg} \mathrm{L}^{-1}\right)\end{array}$ \\
\hline Mn & 1000 & 50 & $0,0.5,1,1.5,2,2.5,3,3.5$ & 0.994 & 0.03 \\
\hline $\mathrm{Pb}$ & 1000 & 50 & $0,0.5,1,1.5,2,2.5,3,3.5$ & 0.998 & 0.09 \\
\hline $\mathrm{Cr}$ & 1000 & 50 & $0,0.5,1,1.5,2,2.5,3,3.5$ & 0.992 & 0.06 \\
\hline Cd & 1000 & 50 & $0,0.25,0.5,1,2,4,5$ & 0.998 & 0.01 \\
\hline
\end{tabular}

Table 1: Concentration values of working standard solutions and Method detection limits.

of enzymes. It was seen that in the work site, the level of Mn ranges (0.420-520 $\mathrm{mg} \mathrm{L}^{-1}$ ) (Table 3). From this, it could be accomplished that $\mathrm{Mn}$ level found in the study area was greater than the standard value given for $\mathrm{Mn}$ by WHO which is $0.05 \mathrm{mgL}^{-1}$. This shows that high traffic density found near the study area played a significant role in the level of $\mathrm{Mn}$ in the Kulufo River water. In line with this, vehicle wheels and increased different factories introduce $\mathrm{Mn}$ into the soil and water body [13]. From this it is possible to conclude that Kulufo river-water' has relatively high concentration of manganese, and its effect on the aquatic systems is relatively high.

Lead $(\mathbf{P b}): \mathrm{Pb}$ is both a toxic and non-essential metal having no nutritional value to living organisms. It was seen that in the work site, the level of $\mathrm{Pb}$ ranges $\left(0.012-0.023 \mathrm{mg} \mathrm{L}^{-1}\right.$ (Table 3). From this, it could be observed that $\mathrm{Pb}$ level found in the study area was greater than the standard value given for $\mathrm{Pb}$ by WHO which is $0.01 \mathrm{mgL}^{-1}$.

This shows that high traffic density found near the study area played a significant role in the level of $\mathrm{Pb}$ in the Kulufo River water. From this it is possible to close that this river-water has relatively high concentration of $\mathrm{Pb}$, and its effect on the aquatic systems is very high. Because of $\mathrm{Pb}$ is very toxic heavy metal even at low concentration. Thus, Kulufo River was not recommended for domestic use.

Chromium (Cr): It was seen that in the work site, the level of $\mathrm{Cr}$ ranges (0.106-0.201 $\mathrm{mg} \mathrm{L}^{-1}$ (Table 3). Thus, $\mathrm{Cr}$ concentrations in the river water were not complying with the set WHO guideline $(0.05 \mathrm{mg}$ $\mathrm{L}^{-1}$, for domestic use) for all of the sampling months. Therefore, Kulufo River water is not safe for domestic use.

Cadmium (Cd): It was seen that in the work site, the level of $\mathrm{Cr}$ ranges (0.050-0.108 $\mathrm{mg} \mathrm{L}^{-1}$ (Table 3). Cd is a non-essential element and is highly toxic to marine and freshwater aquatic life. Cd concentrations in the river water (Table 3) not comply with the set WHO guideline (0.003 $\mathrm{mg} \mathrm{L}^{-1}$, for domestic use) for all of the sampling months. Therefore, Kulufo River water is not safe for domestic use.

\section{Conclusions}

This work focused on the determination of $\mathrm{Mn}, \mathrm{Pb}, \mathrm{Cr}$ and $\mathrm{Cd}$ concentrations in Kulufo River water, Arba Minch, Gamo Gofa. The concentrations of $\mathrm{Mn}, \mathrm{Pb}, \mathrm{Cr}$ and $\mathrm{Cd}$ were determined from the Kulufo River water by using FAAS technique. The results showed that the highest concentrations of $\mathrm{Mn}, \mathrm{Pb}, \mathrm{Cr}$ and $\mathrm{Cd}$ were found from the work areas.

In summary of the obtained results, it has emerged that the highest levels of the selected heavy metals in the work areas were detected in the River water samples collected from Kulufo. This is due to the highest traffic densities present near to the Arba Minch town. The total concentrations of heavy metals $(\mathrm{Mn}, \mathrm{Pb}, \mathrm{Cr}$ and $\mathrm{Cd})$ in the Kulufo River water were above the critical maximum levels (the standard concentrations reported by WHO for drinking water) above which toxicity is possible. From this point view Kulufo River water was contaminated by these metals concentration. Therefore, treatment requires removing this contamination, because the transport flows and the factories are increasing day to day.

\begin{tabular}{|c|c|c|}
\hline Months & pH & EC $(\mathbf{m s} / \mathbf{m})$ \\
\hline April & $7.2 \pm 0.03$ & $11.5 \pm 1.02$ \\
\hline June & $7.3 \pm 0.04$ & $10.5 \pm 0.06$ \\
\hline July & $7.5 \pm 0.02$ & $13.5 \pm 0.04$ \\
\hline August & $7.6 \pm 0.01$ & $13.9 \pm 0.08$ \\
\hline WHO values & $6.5-9.5$ & 600 \\
\hline
\end{tabular}

Table 2: Average levels of Physico-chemical properties of Arba Minch Kulufo River.

\begin{tabular}{|c|c|c|c|c|}
\hline \multirow{2}{*}{ Metals } & \multicolumn{4}{|c|}{ Sampling Months Concentrations mg $\mathbf{L}^{-1}$} \\
\cline { 2 - 5 } & April & June & July & August \\
\hline $\mathbf{M n}$ & $0.49 \pm 0.001$ & $0.52 \pm 0.004$ & $0.43 \pm 0.000$ & $0.42 \pm 0.007$ \\
\hline $\mathbf{P b}$ & $0.021 \pm 0.006$ & $0.023 \pm 0.004$ & $0.013 \pm 0.002$ & $0.012 \pm 0.001$ \\
\hline $\mathbf{C r}$ & $0.199 \pm 0.006$ & $0.201 \pm 0.004$ & $0.108 \pm 0.002$ & $0.106 \pm 0.001$ \\
\hline $\mathbf{C d}$ & $0.106 \pm 0.006$ & $0.108 \pm 0.004$ & $0.067 \pm 0.002$ & $0.05 \pm 0.001$ \\
\hline
\end{tabular}

Table 3: Average levels of $\mathrm{Mn} \mathrm{Pb}, \mathrm{Cr}$ and $\mathrm{Cd}\left(\mathrm{mg} \mathrm{L}^{-1}\right)$ in Kulufo river water.

\section{References}

1. Oluduro AO, Adewoye BI (2007) Efficiency of moringa Oleifera Sead extract on the microflora of surface and ground water. J plant Sci 6: 453-438.

2. Censi P, Spoto SE, Saiano F, Sprovieri M, Mazzola S, et al. (2006) Heavy metals in coastal water systems. A case study from the northwestern Gulf of Thailand. Chemosphere 64: 1167-1176

3. Storelli MM, Storelli A, D'Addabbo R, Marano C, Bruno R, et al. (2005) Trace elements in loggerhead turtles (Caretta caretta) from the eastern Mediterranean Sea: overview and evaluation. Environ Pollut 135: 163-170.

4. Nesa N, Azad P (2008) Studies on trace metal levels in soil and water of Tipong, Tirap and Tikak Collieries of Makum coal, Tinsukia, Assam. Poll Res 27: 237-239.

5. Ozmen H, KAlahci F, Cukurovali A, Dogru M (2004) Concentrations of heavy metal and radioactivity in surface water and sediment of Hazar Lake (Elazig, Turkey). Chemosphere 55: 401-408.

6. Begum A, Amin MN, Kaneco S, Ohta K (2005) Selected elemental composition of the muscle tissue of three species of fish, Tilapia nilotica, Cirrhina mrigala and Clarius batrachus, from the fresh water Dhanmondi Lake in Bangladesh. Food Chemistry 93: 439-443.

7. Fernandes C, Fontaínhas-Fernandes A, Cabral D, Salgado MA (2008) Heavy metals in water, sediment and tissues of Liza saliens from Esmoriz-Paramos lagoon, Portugal. Environ Monit Assess 136: 267-275.

8. Ozturk M, Ozozen G, Minareci O, Minareci E (2008) Determination of heavy metals in of fishes, water and sediment from the Demirköprü Dam Lake(Turkey). Journal of Applied Biological Sciences 2: 99-104.

9. Pote J, Haller L, Loizeau JL, Bravo AG, Sastre V, et al. (2008) Effects of a sewage treatment plant outlet pipe extension on the distribution of contaminants in the sediments of the Bay of Vidy, Lake Geneva, Switzerland. Bioresource Technol 99: 7122-7131.

10. Praveena SM, Radojevic M, Abdullah MH, Aris AZ (2008) Application of sediment quality guidelines in the assessment of mangrove surface sediment in Mengkabong lagoon, Sabah, Malaysia. Iran J Environ Health Sci Eng 5: 35-42.

11. De AK (2007) Environmental Chemistry. New age international limited. New Delhi.

12. Ahmed MF, Rahman MM (2000) Water Supply and Sanitation. ITN-Bangladesh, Centre for Water Supply and Waste Management, BUET, Dhaka, Bangladesh.

13. Viard B, Pihan F, Promeyrat S, Pihan JC (2004) Integrated assessment of heavy metal $(\mathrm{Pb}, \mathrm{Zn}, \mathrm{Cd})$ highway pollution: bioaccumulation in soil, Graminaceae and land snails. Chemosphere 55: 1349-1359. 